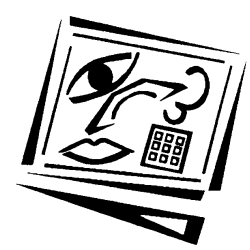

Australasian Journal of

Educational Technology

2004, 20(3), 337-350

\title{
Computer skills development by children using 'hole in the wall' facilities in rural India
}

Parimala Inamdar

Center for Research in Cognitive Systems, NIIT Ltd, India

Earlier work often referred to as the "hole in the wall" experiments has shown that groups of children can learn to use public computers on their own. This paper presents the method and results of an experiment conducted to investigate whether such unsupervised group learning in shared public spaces can improve children's performance in school examinations. The experiment was conducted with "hole in th (minimally invasive education, or MIE) kiosks in the (minimally invasive education, or MIE) kiosks in the rural Sindhudurg District of Maharashtra State, India. 103 children of the Grade 8 level, across 3 villages, were administered the curricular examination for 'Computer Science' for that grade.

The results show that children who had learned at MIE kiosks were able to complete this curricular examination without being taught the subject. T comed the scored only marginally lower than children who had been taught the 'Computers' curriculum in school throughout the school year. The results of this study throw new light on pedagogy for bridging the digital divide. It poses the question that similar learning may well be observed in whole or part in other subjects of the school curriculum.

\section{Introduction}

It has been observed that children are able to learn to use computers and the Internet on their own, irrespective of their social, cultural or economic backgrounds (Mitra and Rana, 2001). The press labeled these experiments, first conducted in 1999, as "hole in the wall" experiments (see, for example, Padmakar and Porter, 2001), because the experimental arrangement consisted of computers built into openings in brick walls in public spaces.

The experiments were first conducted in Kalkaji, a suburb of New Delhi, India. A computer was connected to the Internet and embedded into a brick wall near a slum. It was reported that most of the slum children were able to use the computer to browse, play games, create documents and 
paint pictures within a few days. The results have, since then, been reported in detail, elsewhere (see, for example, Frontline World 2002, Education Guardian 2000, Businessweek Online 2000, Mitra 2000, Mitra 2003 and Wullenweber 2001).

The experiments were described by Mitra and Rana as "minimally invasive", a term borrowed from surgery (Mitra and Rana 2001, Mitra 2003), and indicative of minimal human intervention. Mitra further explained the term in an interview to Businessweek Online.

I'm saying that, in situations where we cannot intervene very frequently, you can multiply the effectiveness of 10 teachers by 100 - or 1,000 - fold if you give children access to the Internet.... This is a system of education where you assume that children know how to put two and two together on their own. So you stand aside and intervene only if you see them going in a direction that might lead into a blind alley. That's just so that you don't waste time... (Mitra, Businessweek Online 2000)

Presently, such "Hole in the wall" facilities, also known as "Minimally Invasive Education kiosks" (MIE kiosks) have been set up in 22 rural and urban locations across India and similar results are reported through field observations as well as through the GUI Icon Association Inventory test (Mitra 2003) administered to children. Observations across locations show a learning process of random exploration, collaboration, discovery, vocabulary construction, generalisation, practice and peer tutoring (Mitra and Rana 2001, Mitra 2003). The kiosk experiments are being repeated in Egypt, South Africa and Cambodia.

A design for kiosks meant for use by children in outdoor environments has been developed and tested in various experiments, and is considered robust.

In what follows, we are testing the following hypotheses:

If given appropriate access, connectivity and content, groups of children can learn to operate and use computers and the Internet to achieve a

specified set of the objectives of primary education, with none or minimal intervention from adults.

The intent of this paper is to present the results of an empirical investigation. Placing these results in a theoretical framework is not the intent of this paper.

\section{Background for this experiment}

In April 2002 five MIE kiosks were opened in villages of the Sindhudurg district of Maharashtra State, India. This district claims almost 100\% 
literacy with a population of about 830,000 of which about $93 \%$ lives in villages. It covers about $5000 \mathrm{sq}$ kilometers and has a $160 \mathrm{~km}$ coastline. It has about 1500 primary schools and 180 secondary schools. Each kiosk in the Sindhudurg district houses 2 computers and incorporates special design features for public access, tropical conditions, remote monitoring, and children's usage. The MIE kiosks here offer an English language Microsoft Windows environment.

Three kiosks were connected to the Internet via VSAT in June 2004, when the final version of this paper was written. Access to Internet content is also provided in an offline form. The offline content includes educational games and freeware from the Internet, mostly in English.

The kiosks in Sindhudurg are fitted with TOBU mice and keyboards as input devices. The design for these has evolved over the years since the first 'hole in the wall' in 1999. At the time, a touch pad was the input device embedded in the wall next to the monitor. Between 1999-2000 these off the shelf touch pads were replaced with custom made, joystick style mice. Although this did significantly increase the mean time between failures, the mechanical failures in these were not entirely eliminated. This led to the development of a six-button mouse, deployed in many kiosks. However, in humid and corrosive air, such as near tropical oceans, the switches in these mice developed faults. Finally, the development of the capacitative TOBU mouse in 2003 by the laboratories of NIIT's Center for Research in Cognitive Systems solved the problem of an outdoor pointing device. This mouse is entirely solid state and has no moving parts. Eightyeight of these have been in operation for over a year in all parts of India.

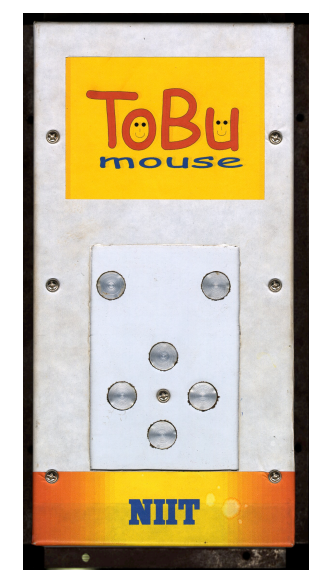

Figure 1: Photo of the TOBU Mouse 
Also, the first experiment of 1999 did not provide for keyboard access, as architectural designs for protecting standard keyboards in public access environments were not developed at the time. Since then NIIT has developed a sturdy cowl to protect keyboards with enough space for a child's hands to go through and access. The touch button mice are now embedded within the cowl keyboard structure. Over the 4-year period from 1999-2003, research in engineering design has made the present input devices rugged and tamper proof.

Each machine contains a remote monitoring software program to track usage of various software applications in the machines, as well as environmental conditions.

The kiosks are placed in playgrounds or close to schools (Figures 2 and 3). Rural children between the ages of 8-14 are presently using these kiosks, many with no previous exposure to computers. The local language is Marathi. This is also the language of instruction in the village schools. English is learned as a second language from Grade 1.

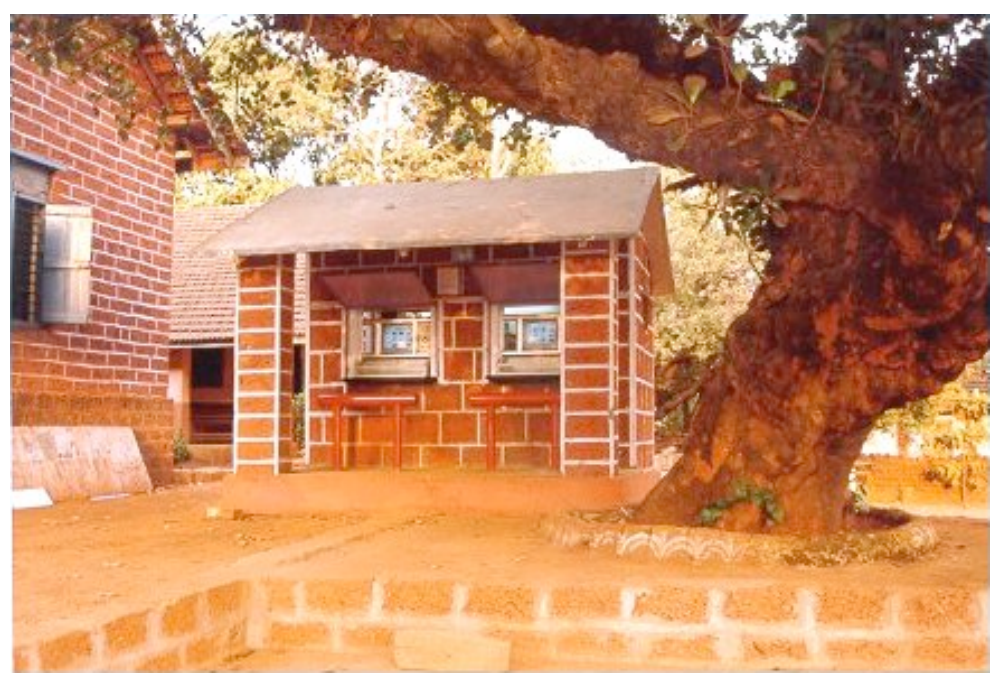

Figure 2: Photo of an MIE kiosk, Sindhudurg

"Computers" is offered as an optional subject in some village schools at the Grade 8 level along with leatherwork, sewing and carpentry. Only a few are selected into the computer class at school, due to limited capacity. Selection depends on merit and past academic performance. 
In June 2002 a local computer teacher reported a saving of $10 \%$ of his teaching time in the computers class because his students had been exploring at the kiosk (Attar, June 2002). This gave us reason to conjecture that students who were not part of the school computer class may well be able to attempt some part of the curricular examination without being taught. To probe this further, in November 2002 we conducted a short study, to see how children who have learned at MIE kiosks fare on the Grade 8 examination for the Computer Science syllabus, without being taught the syllabus.

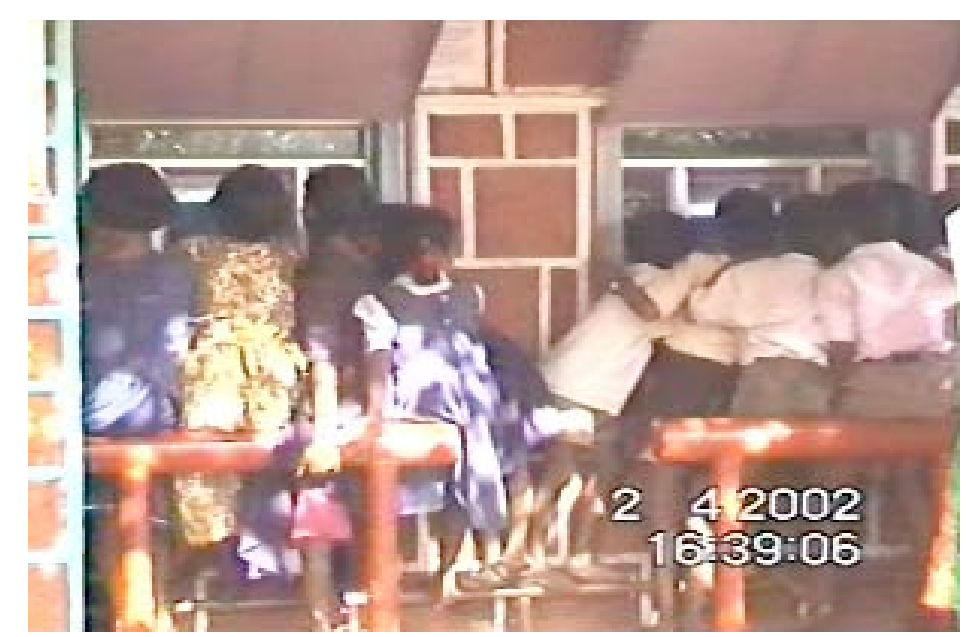

Figure 3: Photo of children at the kiosk

Six children aged thirteen years (three boys and three girls) were tested on a 2 hour 45 minute curricular examination in computer science. The exam was worth a total of 100 marks, split between 'theory' (60 marks) and 'practicals' (40 marks). The minimum score required for passing the examination was $35 \%$. All six students passed the practical exam with very good scores. Two students were close to passing the theory examination, while four did not. The results were intriguing.

We decided to examine larger numbers of children through an experimental study of MIE children's performance on two aspects of the Grade 8'Computers' exam:

1. The 'practical', or hands on examination, given no instructional inputs.

2. The theory examination, if the learning material, in the form of the prescribed textbook, was given to them. 


\section{Sub hypothesis}

Groups of children with appropriate public access to the computers and the Internet can meet the minimum levels required by the

Maharashtra State Education Board computers syllabus for Grade 8,

with none or minimal intervention from adults

\section{Population}

School going rural children aged 12-13 years, of Maharashtra State, Sindhudurg District, with access to MIE kiosks.

\section{Profiles of groups}

Table 1 below shows the profiles of 3 groups that were part of the experimental study. The experimental group was drawn randomly from among MIE kiosk users of villages Shirgao and Kalse. Control Group A was drawn randomly from a village that has no computers in school or MIE kiosk. Control Group B comprised students from a "computers" class of Shirgao High School.

Table 1: Profiles of groups

\begin{tabular}{|l|c|c|c|c|c|c|c|c|}
\hline Group & Villages & $\begin{array}{c}\text { Number } \\
\text { Male } \\
\text { Female }\end{array}$ & Age & $\begin{array}{c}\text { MIE } \\
\text { kiosk } \\
\text { learn- } \\
\text { ing }\end{array}$ & $\begin{array}{c}\text { Classroom } \\
\text { computer } \\
\text { teaching }\end{array}$ & $\begin{array}{c}\text { Hours of } \\
\text { computer } \\
\text { handling/ } \\
\text { exposure }\end{array}$ & $\begin{array}{c}\text { English } \\
\text { language } \\
\text { teaching } \\
\text { in school }\end{array}$ & $\begin{array}{c}\text { Medium } \\
\text { of inst- } \\
\text { ruction }\end{array}$ \\
\hline $\begin{array}{l}\text { Experim- } \\
\text { ental } \\
\text { Group }\end{array}$ & $\begin{array}{l}\text { Kalse }+ \\
\text { Shirgao }\end{array}$ & $\begin{array}{c}\mathrm{N}=30 \\
12 \mathrm{~F}+18 \mathrm{M}\end{array}$ & $12-13$ & Yes & No & $\begin{array}{c}\text { At least } \\
20 \text { hours }\end{array}$ & Yes & Marathi \\
\hline $\begin{array}{l}\text { Control } \\
\text { Group A }\end{array}$ & Kuvle & $\begin{array}{c}\mathrm{N}=31 \\
16 \mathrm{~F}+15 \mathrm{M}\end{array}$ & $12-13$ & No & No & 0 hours & Yes & Marathi \\
\hline $\begin{array}{l}\text { Control } \\
\text { Group B }\end{array}$ & Shirgao & $\begin{array}{c}\mathrm{N}=42 \\
38 \mathrm{~F}+4 \mathrm{M}\end{array}$ & $12-13$ & Yes & Yes & $\begin{array}{c}\text { At least } \\
20 \text { hours }\end{array}$ & Yes & Marathi \\
\hline
\end{tabular}

\section{Method}

As described above there were 3 groups:

- Experimental Group - MIE students $(\mathrm{N}=30)$ drawn from villages Shirgao and Kalse

- Control Group A - computer illiterate students $(\mathrm{N}=31)$ drawn from village Kuvle

- Control Group B - classroom computers students $(\mathrm{N}=42)$ drawn from village Shirgao 
All students were tested on the Grade 8 examination of the Computer Science syllabus in two phases in February to March 2003. All the examinations were conducted in Marathi, the language of instruction.

The first phase tested the students on the practical examination. The 70minute practical examination was conducted on all 3 groups at the computer lab facilities of Shirgao High School and Kalse High School. The student to machine ratio was 1:1. Each student was handed a question set of exercises.

In the second phase, the theory examination was administered to all groups. Prior to the examination, each of the students in the experimental group was handed the Grade 8 'Computers' textbook and was told that the exam would follow in a month. Control Group A was not handed the book, to check the results given no inputs whatsoever. The book is a standard text used for curricular teaching for Control Group B.

All 3 groups were administered the 90-minute written theory examination in their respective schools (Table 1). The examination was conducted in Marathi, the language of instruction. This was followed by an oral examination of 5 minutes per student, conducted in Marathi.

A schoolteacher from Shirgao who teaches computers set the examination papers, monitored the examination as well as graded all students. All of these activities were conducted as per Maharashtra State Education Board norms. The computer teacher is a Maharashtra State Education Board examiner as well as moderator. The author was present as observer of evaluation methods.

Table 2: Description of the examination

(questions in 'Content' column are translated from Marathi)

\begin{tabular}{|c|c|c|c|}
\hline Type of exam & Content & $\begin{array}{c}\text { Evaluation } \\
\text { criteria }\end{array}$ & Comments \\
\hline $\begin{array}{l}\text { PRACTICAL } \\
\text { Duration } 40 \\
\text { minutes } \\
20 \text { marks }\end{array}$ & $\begin{array}{l}\text { Students were given } 2 \text { of a bank of } \\
4 \text { exercises. Each to be done in } 20 \\
\text { minutes. } \\
\text { Exercise 1: Using the mouse } \\
\text { - Select the My Computer icon } \\
\text { - Open the My Computer icon } \\
\text { - Close the My Computer opened } \\
\text { icon } \\
\text { - Right click on desktop and open } \\
\text { properties } \\
\text { - Drag the My Computer icon } \\
\text { Exercise 2: Shut down the } \\
\text { computer }\end{array}$ & $\begin{array}{l}\text { Each exercise } \\
\text { worth } 10 \\
\text { marks. } 2 \\
\text { marks for } \\
\text { each step } \\
\text { executed. }\end{array}$ & $\begin{array}{l}1 \text { to } 1 \text { student } \\
\text { machine ratio } \\
\text { Students } \\
\text { have not } \\
\text { used a mouse } \\
\text { before. }\end{array}$ \\
\hline
\end{tabular}




\begin{tabular}{|c|c|c|}
\hline & $\begin{array}{l}\text { - } \text { Click on 'Start' } \\
\text { - } \text { Choose 'Shutdown' option } \\
\text { - } \text { chom the Shutdown window 'Shutdown' option } \\
\text { - Click on the 'OK' button in the } \\
\text { - Shutdown window } \\
\text { Exercise 3: Opening Date time and } \\
\text { changing time, year and month } \\
\text { - Open clock } \\
\text { - Choose month of May } \\
\text { - Choose year } 2007 \\
\text { - } \text { Choose time } 9.10 \\
\text { Exercise } 4: \text { Handling programs: } \\
\text { - Open the Program called Paint } \\
\text { - Minimise it } \\
\text { - Maximise it } \\
\text { - Draw a pretty picture } \\
- \text { Close the program }\end{array}$ & \\
\hline $\begin{array}{l}\text { WORKBOOK } \\
\text { PROCESS } \\
\text { NOTE } \\
\text { Duration } 30 \\
\text { minutes } \\
20 \text { marks }\end{array}$ & $\begin{array}{l}\text { Students were given } 1 \text { of a bank of } \\
2 \text { exercises to do as per instructions } \\
\text { given to them. They are supposed } \\
\text { to follow some of the steps, execute } \\
\text { some others by themselves and } \\
\text { write down their observations of } \\
\text { the process / method on paper. The } \\
2 \text { exercises: } \\
\text { 1. Using numeric keypad with } \\
\text { cursor control keys and numeric } \\
\text { keys } \\
\text { 2. Using the Start Menu }\end{array}$ & $\begin{array}{l}8 \text { marks for } \\
\text { the written } \\
\text { note. } 12 \text { marks } \\
\text { based on } \\
\text { teacher's } \\
\text { observation of } \\
\text { the method } \\
\text { employed by } \\
\text { child, help } \\
\text { taken, and } \\
\text { task } \\
\text { completion. }\end{array}$ \\
\hline \begin{tabular}{|l} 
THEORY \\
Duration 90 \\
minutes \\
50 marks
\end{tabular} & $\begin{array}{l}\text { Fill In the Blanks } 6 \text { marks; Match } \\
\text { the following } 4 \text { marks; True or false } \\
6 \text { marks; Describe process } 4 \text { marks; } \\
\text { Describe the differences } 4 \text { marks; } \\
\text { Name the following based on the } \\
\text { given description } 6 \text { marks; Short } \\
\text { notes } 6 \text { marks; Describe method } 4 \\
\text { marks; Short answers } 10 \text { marks }\end{array}$ & $\begin{array}{l}\text { Model answer } \\
\text { paper }\end{array}$ \\
\hline $\begin{array}{l}\text { ORAL } \\
\text { Duration } 5 \text { mins } \\
10 \text { marks }\end{array}$ & & \\
\hline
\end{tabular}

\section{Observations during the practical exam}

The computers examination process itself was a challenging and novel experience for the Experimental Group and Control Group A because: 
1. None in the Experimental Group or Control Group A had any exposure to the computer syllabus or teaching. Hence, computer vocabulary was largely unfamiliar to them. They were not familiar with questions like "open the program WordPad". However, the experimental group interpreted the questions in the context of their own experience and responded.

2. Both Experimental Group and Control Group A were unfamiliar with the examination pattern. Hence the process of the examination was novel to them. The act of following one instruction at a time in a given set of questions was a pattern they were not prepared for, but had to follow. While this confounded the Control Group A, the Experimental Group grappled well with it.

3. Both Experimental and Control Group A had not used a conventional mouse prior to the examination. At MIE kiosks children use a TOBU mouse device with six buttons (Figure 1). Hence the Experimental Group, although not familiar with using the conventional mouse, was conceptually familiar with mouse operations, and was quickly able to adapt to using the conventional mouse for clicking, double clicking and dragging.

4. In the 'Process Note' examination, students were given some steps to do and had to write down the process and its results. It was seen that the Experimental Group needed to be reminded to write down their observations of what they were doing. They would often execute all the steps and forget about writing them down. They were untrained in this method, but did well.

5. Children in the Experimental Group sometimes understood a question as a task and accomplished the task in alternate ways. One child in the experimental group found an alternative way of opening Microsoft Word. However the instruction for the Process Note was to 'open' through "Run". These alternate methods were not given marks in the practical examination where the emphasis was on following instructions.

\section{Results overview}

In spite of the factors mentioned above, the students of the Experimental Group showed outstanding results in the Grade 8 Computers examination. This was worth a total of 100 marks, split between 'theory' (60 marks) and 'practicals' (40 marks). The minimum score required for passing the examination was $35 \%$. In summary: 
- $87 \%$ of the Experimental Group passed the practical examination.

- $67 \%$ of the Experimental Group scored over $60 \%$ (classified as 1st Class) in the practical examination

- The highest overall score (theory+practical) in the Experimental Group was $62 \%$, the same in the Control Group B was $69 \%$ and in the control group A was $14 \%$

- $88 \%$ of the Experimental Group passed the complete examination

- All of the Control Group B passed the complete examination

- None of the Control Group A passed the examination

- The average score for the Experimental Group was $47 \%$

\section{Comparing group results}

The graphs below show a comparison of scores between the three groups on overall averages, practical examination averages and theory examination averages.

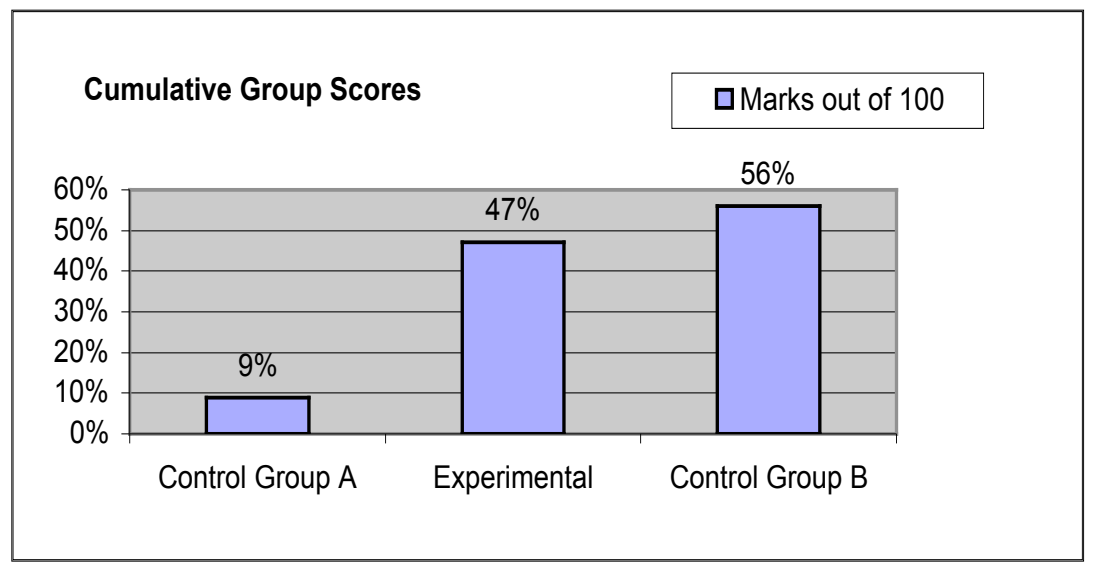

Figure 4: Cumulative group scores

Figure 4 shows the average group scores of the Experimental Group at $47 \%$, Control Group B 56\%, and Control Group A 9\%. The higher overall average for Control Group B was due to higher scores in the theory examination. Control Group A attained 9\% despite having no exposure to computers prior to the examination. There could be several reasons for this:

- Learning gained from the first 40 minutes of being exposed to computers during the practical examination

- Marks gained from randomly chosen answers to multiple choice questions

- Some rudimentary prior knowledge gained from hearsay or media 
Figure 5 compares the practical examination results of all three groups. It shows that the Experimental Group's scores in the practical examination are ahead of the other groups. The Experimental Group is at 23 marks, the Control Group B at 22 marks and the Control Group A at 2 marks.

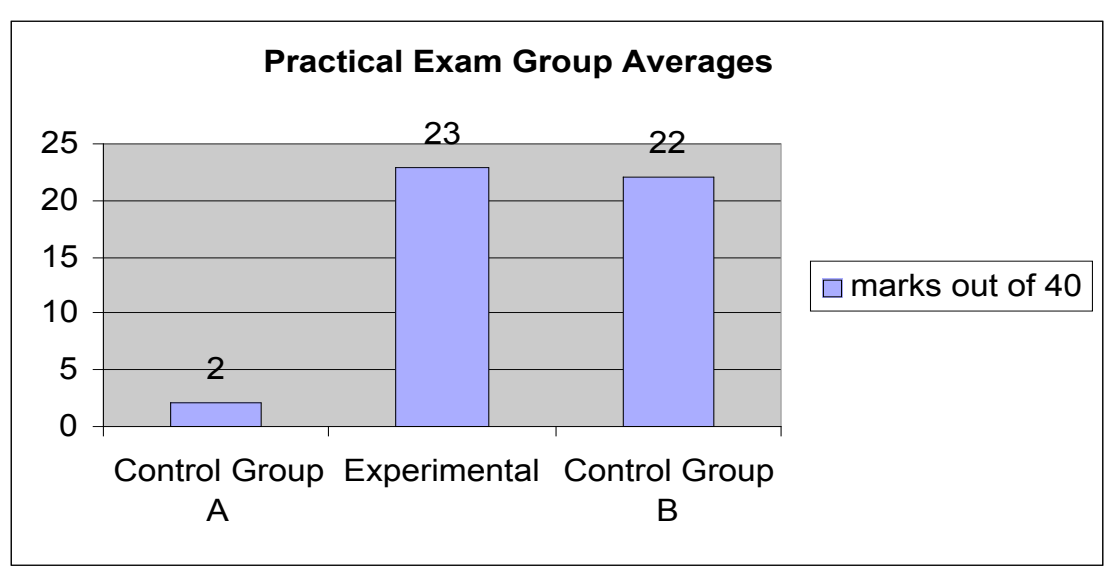

Figure 5: Practical exam group averages

Figure 6 compares the average group scores on the theory examination. The Control Group B leads at 33 marks out of 60, the Experimental Group is at 25 and the Control Group $\mathrm{A}$ is at 7.

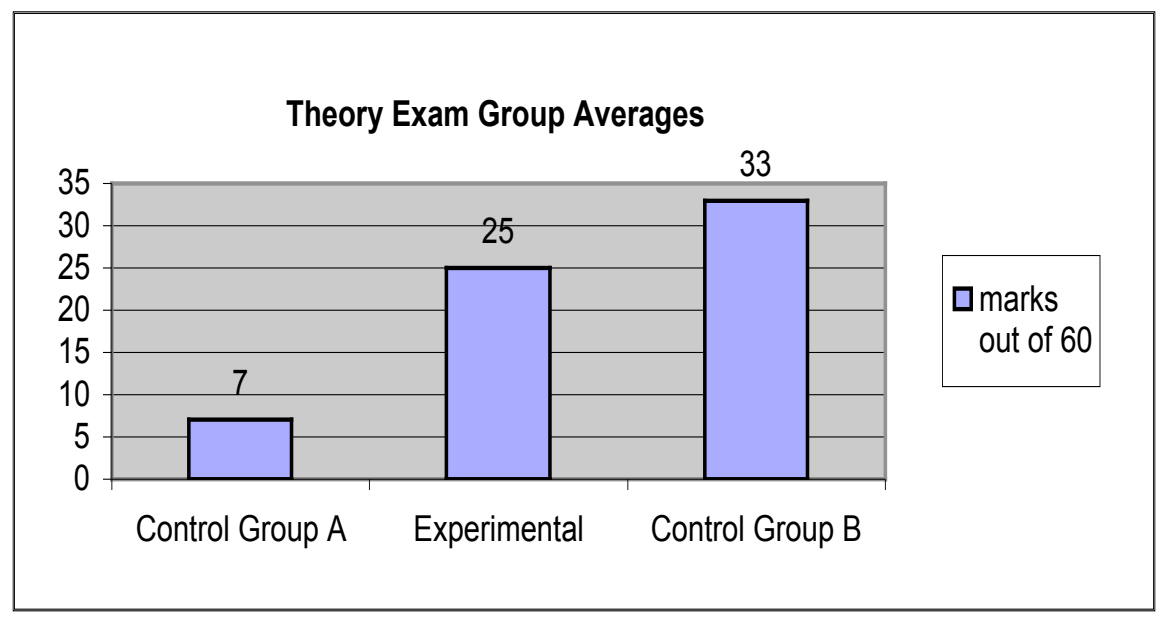

Figure 6: Theory exam group averages 


\section{Discussion and conclusions}

\section{Objectives of primary education}

In the process of using the MIE kiosks children have gained knowledge and skills in computing. Going further, the children proved that the method of learning while using MIE kiosks gave them enough knowledge and skills to pass the Grade 8 curriculum examination for Computer Science, meeting an objective of primary education. It is possible that children of a younger age with exposure to MIE kiosks may also pass this examination.

It is also quite likely that this mode of unsupervised group learning through the computer is impacting subject knowledge for other subjects.

There is considerable learning material as well as games stored on these machines. Three of the MIE locations mentioned in this paper were connected to the Internet through VSAT in June 2004. The impact of this is an area for future research.

\section{Curriculum delivery}

MIE student results compare very well with children who have been taught the computers curriculum for a year in Grade 8. They succeeded not only at 'practicals' but also passed the theory when given the textbook. This is a significant finding.

It is postulated that curriculum can be divided into three bands, in order for learners to acquire the necessary competence (Mitra 2003):

1. A band that needs a human teacher who is conversant with the subject matter and teaching methodology

2. A band that needs an assistant who is somewhat more knowledgeable than the learner

3. A band that needs resources and a peer group alone

The MIE kiosk environment fosters learning in band 3. The Grade 8 computers curriculum is identified, as a result of this study, as fitting into band 3. The results presented in this paper seem to indicate that this part of the school curriculum needs resources and a peer group alone. Changes in delivery of this could free up significant amounts of teacher and institutional time to other parts of curriculum that fall into band 1 . 


\section{Serving the economically and academically disadvantaged}

By the schoolteacher's admission (Attar 2002), in the process of selection, the brightest students are taken for the school computers class. The rest join other options like leatherwork or sewing. Students who are left out but wish to study computers, join a technical school nearby, if they can afford the fees. In our experiment, children from the experimental group were those who were not admitted into the computer class in their own school or the nearby technical school. Results show that MIE kiosks are effectively able to serve this section of the community of children - the economically or academically disadvantaged.

\section{On kiosk learning environment design}

The design of the present environment was able to deliver a learning experience that meets one objective of school education - common computing skills. The kiosk enclosure, ergonomically designed to facilitate children's group behaviour/use, and the software resident on the machine presents an adequate environment to generate a level of motivation to induce learning in this subject.

\section{Next steps}

We intend to test the academic impact of the Internet connected as well as unconnected kiosks on other curricular subjects over the next year. This could provide further proof of the fact that the 'hole in the wall' can indeed enable groups of children to meet some of the objectives of primary education, on their own.

\section{Acknowledgements}

- I wish to thank Sugata Mitra for his guidance and comments

- Financial assistance from NIIT Limited, the Government of Delhi, the ICICI bank and the International Finance Corporation is gratefully acknowledged.

- I wish to thank schoolteacher Shamsuddin Attar of Shirgao High School, Sindhudurg, India for conducting the examination and grading the papers.

- This experiment would not have been possible without the support of the school principals and the use of school premises during the course of the examinations in Shirgao, Kalse and Kuvle village.

- I wish to thank my colleagues at the Center for Research In Cognitive Systems - Sanjay Gupta, Ravi Bisht and Ritu Dangwal - for their cooperation and support. 


\section{References}

Attar, S. (2002). Personal communication.

Bytesforall (2002). Village kinds [kids] find computers a useful, simple toy.

http: / / mail.sarai.net/ pipermail / bytesforall/2002-July / 000111.html [verified 10 Aug 2004]

EducationGuardian.co.uk (2002). Slum children get free Internet access. Education Guardian, 17 Oct 2000. [verified 10 Aug 2004]

http: / / education.guardian.co.uk/Distribution / Redirect_Artifact/ 0,4678,0383459,00.html

Frontline/World (2002). Kids-eye view: Looking through the hole in the wall. FRONTLINE/World, October. [verified 10 Aug 2004] http: / / www.pbs.org/ frontlineworld/stories/india/kids.html

Mitra, S., Tooley, J., Inamdar, P. and Dixon, P. (2003). Improving English pronunciation - an automated instructional approach. Information Technologies and International Development, 1(1), 75-84, MIT Press.

Mitra, S. and Rana, V. (2001). Children and the Internet: Experiments with minimally invasive education in India. The British Journal of Educational Technology, 32(2), 221-232.

Mitra, S. (2000). Minimally invasive education for mass computer literacy. Presented at the CRIDALA 2000 conference in Hong Kong, 21-25 June.

Mitra, S. (2003). Minimally Invasive Education: A progress report on the "Hole-inthe-wall" experiments. British Journal of Educational Technology, 34(3), 367-371.

Padmakar, P. and Porter, H. (2001). The hole in the wall machine. Time Magazine, Asian edition, 3 September, p.16.

Sweatshops and Butterflies (2001). India: Hole-in-the-Wall. [verified 10 Aug 2004] http: / / www.greenstar.org/butterflies/Hole-in-the-Wall.htm

The "Hole-In-The-Wall" (2003). [verified 10 Aug 2004] http:/ / www.niitholeinthewall.com/

Wullenweber, Walter (2001). Das loch in der wand. Stern Magazine, No. 42, 11 October, pp 97-102.

\begin{tabular}{|l|}
\hline Parimala Inamdar \\
Center for Research in Cognitive Systems, NIIT Ltd \\
Corduroy Building, Aditya Textile Compound \\
Safed Pool, Andheri East \\
Mumbai 400072, India \\
Email: parimalai@niit.com \\
Website: http:/ / www.niitholeinthewall.com
\end{tabular}

